\title{
Research on System Dynamics of Highway Construction Effects on Socio-economic Benefit
}

\author{
Zhi-yu Chen ${ }^{1, \text { a * }}$ \\ XiTuCheng Road $8^{\text {th }}$, HaiDian Distinct, Beijing, China \\ chenkitty7799@126.com Tel: 15801669665
}

\section{Keywords: Highway; Economic Benefits; Social Benefit; System Dynamics}

Abstract. Highway construction obviously led to the social and economic benefits. This article uses the basis data of economic and social statistics in 2005-2014 of Guangdong Province, combines the qualitative and quantitative methods, Index system and analyze the impact of the economic and social benefits of the highway, establish and simulation the system dynamics causal diagram and system dynamics flow diagram. Research on the effects of highway construction of the socio-economic within the system dynamic model, proposed the method of development and construction of the highway project. Provide theoretical support of relevant policy recommendations to promote economic and social development to give full play to highway function ${ }^{1}$.

\section{Introduction}

Transportation is a nonprofit community-based service system, as an important part of the essential, highway linked with all walks of life, highway has a significant effect for economic, social promotion. The economic benefits of the process of building the highway project is limited, however, after completion of the project, it direct and indirect impact on the economy and society is far greater than investment in highway construction. This paper combined with the requirements of government departments closely, research on the influence of Expressways on the socio-economic, estimating the different social and economic benefits under different investments of highway.

This paper researches the socio-economic impact of highway, aim to establish a more accurate and quantitative method of highway construction, evaluation and calculation the impact of social and economic of highway. Construction a model which uses data to illustrate the effect of the economic and social impact of highway.All manuscripts must be in English, also the table and figure texts, otherwise we cannot publish your paper.

\section{The significance of System Dynamics Research on the Impact of Socio-economic of Highway Construction.}

This study has important significance both in theory and practice. The research improves the investment decision-making ability of highway construction. The study deepens the method of the impact of socio-economic of highway construction. The study could establish the foundation of the impact of socio-economic of highway construction

Through establish the model to make a comprehensive analysis of the factors affecting by the highway construction on socio-economic. Finding the optimal results of the model. To sum up the research of mechanism of the impact of socio-economic of highway construction and presented the optimization theory. The research could guide the planning theory and evaluation methods.

\section{Establishing the model of the impact of socio-economic of highway construction}

Establishing the Index System

To establish the system dynamics model, it is necessary to determine the evaluation index system of highway construction on the economic and social impact. 
Tab.1 Evaluation System of Highway Construction to Socio-economic

\begin{tabular}{|c|c|c|}
\hline $\begin{array}{c}\text { Firstly } \\
\text { indicators } \\
\text { System } \\
\text { amount } \\
\end{array}$ & $\begin{array}{c}\text { Secondary } \\
\text { indicators } \\
\text { Feature amount }\end{array}$ & $\begin{array}{l}\text { Tertiary indicators } \\
\text { Explanation amount }\end{array}$ \\
\hline \multirow{7}{*}{$\begin{array}{c}\text { Economic } \\
\text { impact }^{2} \\
\text { A1 }\end{array}$} & \multirow{4}{*}{$\begin{array}{c}\text { Capital }^{3} \\
\text { B1 }\end{array}$} & C1: GDP \\
\hline & & C2: Total Investment in fixed assets ${ }^{5}$ \\
\hline & & $\begin{array}{l}\text { C3: Total fetail sales of consumer } \\
\text { coods }^{6}\end{array}$ \\
\hline & & C4: Per capita GDP \\
\hline & \multirow{3}{*}{$\begin{array}{l}\text { Structure } \\
\quad \text { B2 }\end{array}$} & C5: Primary Industry added value \\
\hline & & C6: Secondery industry added value \\
\hline & & C7: Tertiary Industry added value $^{7}$ \\
\hline \multirow{7}{*}{$\begin{array}{c}\text { Social } \\
\text { Impact }^{8} \\
\text { A2 }\end{array}$} & \multirow{2}{*}{$\begin{array}{l}\text { Life } \\
\text { B3 }\end{array}$} & C8: Regional population ${ }^{9}$ \\
\hline & & C9: Employed population ${ }^{10}$ \\
\hline & \multirow{3}{*}{$\begin{array}{c}\text { Traffic } \\
\text { B4 }\end{array}$} & C10: Highway passenger turnover ${ }^{11}$ \\
\hline & & C11: Highway freight turnover ${ }^{12}$ \\
\hline & & C12: Road network density \\
\hline & \multirow{2}{*}{$\begin{array}{l}\text { Tourism } \\
\text { B5 }\end{array}$} & C13: Tourism revenue \\
\hline & & C14: Tourist arrivals \\
\hline
\end{tabular}

Establishing System dynamics flowchart

In order to describe the system configuration clearly, System Dynamics uses the concept of "flow" to describe the decision-making process and build the flow graph model by a special symbols. The next step is to establish a flow graph model, which could make the computer to recognize the causation within the system ${ }^{13}$.

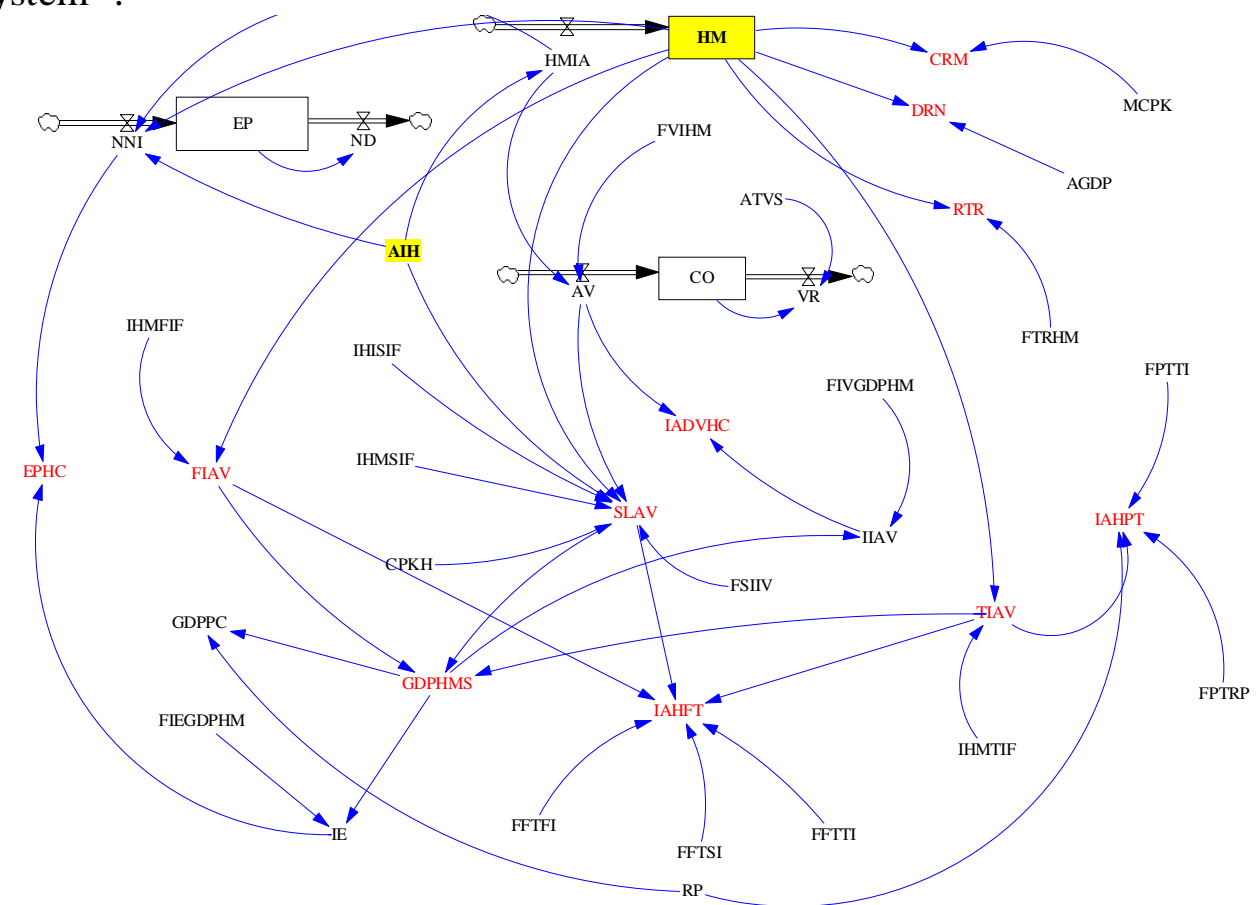

Fig.1 System Dynamics Model flow diagram of "Highway-- Socio-economic"

Establishing the flow diagram to determine the mathematical relationship model from each quantitative to variables. It could build a foundation for running the model ${ }^{14}$. 
Tab.2 Meaning of the symbol in the Flow Diagram

\begin{tabular}{|c|c|c|c|}
\hline No. & definition & implication & unit \\
\hline 1 & HM & Highway mileage & KM \\
\hline 2 & $\mathrm{AIH}$ & Annual investment Highway & One hundred million yuan \\
\hline 3 & HMIA & Highway mileage increased amount & KM \\
\hline 4 & FIAV & Primary Industry added value & One hundred million yuan \\
\hline 5 & SIAV & Secondary Industry added value & One hundred million yuan \\
\hline 6 & TIAV & Tertiary Industry added value & One hundred million yuan \\
\hline 7 & GDPHMS & GDP increment of highway mileage stimulation & One hundred million yuan \\
\hline 8 & IAHFT & Increasing amount of highway freight turnover & $\begin{array}{l}\text { One hundred million tons per } \\
\text { kilometer }\end{array}$ \\
\hline 9 & IAHPT & Increasing amount of highway passenger turnover & $\begin{array}{l}\text { One hundred million person } \\
\text { per kilometer }\end{array}$ \\
\hline 10 & NNI & The number of new inauguration & Ten thousand people \\
\hline 11 & EP & Employed population & Ten thousand people \\
\hline 12 & ND & The number of departure & Ten thousand people \\
\hline 13 & IE & Indirect employment & Ten thousand people \\
\hline 14 & EPHC & Employed population from highway construction & Ten thousand people \\
\hline 15 & $\mathrm{RP}$ & Regional population & Ten thousand people \\
\hline 16 & CRM & The cost of Road maintenance & yuan \\
\hline 17 & DRN & The density of road network & Dimensionless \\
\hline 18 & RTR & Regional tourism revenue & One hundred million yuan \\
\hline 19 & $\mathrm{CO}$ & Car ownership & Ten thousand vehicles \\
\hline 20 & AV & The addition of vehicle & Ten thousand vehicles \\
\hline 21 & VR & vehicle reduction & Ten thousand vehicles \\
\hline 22 & IIAV & The Indirectly increasing amount of vehicle & Ten thousand vehicles \\
\hline 23 & IADVHC & The increase amount of drive vehicles by highway construction & Ten thousand vehicles \\
\hline 24 & MCPK & Maintenance cost per kilometer & yuan \\
\hline 25 & AGDP & Area of Guangdong province & Million passenger-kilometer \\
\hline 26 & ATVS & The average time of vehicle scrapped & year \\
\hline 27 & $\mathrm{CPKH}$ & Consumables of per kilometer highway & Ton \\
\hline 28 & GDPPC & GDP per capita & yuan \\
\hline 29 & IHMFIF & The influence of highway mileage of primary industry factor & Dimensionless \\
\hline 30 & IHISIF & The influence of highway investment of secondary industry factor & Dimensionless \\
\hline 31 & IHMSIF & The influence of highway mileage of secondary industry factor & Dimensionless \\
\hline 32 & IHMTIF & The influence of highway mileage of tertiary industry factor & Dimensionless \\
\hline 33 & FIEGDPHM & $\begin{array}{l}\text { The impact factor of indirect employment from the stimulation of } \\
\text { GDP highway mileage }\end{array}$ & Dimensionless \\
\hline 34 & FIVGDPHM & $\begin{array}{l}\text { The impact factor of indirect vehicle from the stimulation of GDP } \\
\text { highway mileage }\end{array}$ & Dimensionless \\
\hline 35 & FFTFI & The impact factor of freight turnover from the primary industry & Dimensionless \\
\hline 36 & FFTSI & The impact factor of freight turnover from the secondery industry & Dimensionless \\
\hline 37 & FFTTI & The impact factor of freight turnover from the tertiary industry & Dimensionless \\
\hline 38 & FPTTI & The impact factor of passenger turnover from the tertiary industry & Dimensionless \\
\hline 39 & FTRHM & The impact factor of tourism revenue from Highway mileage & Dimensionless \\
\hline 40 & FVIHM & $\begin{array}{l}\text { The impact factor of vehicle from the increase of Highway } \\
\text { mileage }\end{array}$ & Dimensionless \\
\hline 41 & FSIIV & $\begin{array}{l}\text { The impact factor of secondary industry from the increase of } \\
\text { Vehicle }\end{array}$ & Dimensionless \\
\hline 42 & FPTRP & $\begin{array}{c}\text { The impact factor of passenger turnover from the Regional } \\
\text { population }\end{array}$ & Dimensionless \\
\hline
\end{tabular}

System Simulation and Analysis

Highway construction played a leading role to the factors of socio-economic by running the model. This paper collected the data of highway construction and national economic statistics of Guangdong Province 2006-2014.Using system dynamics model to simulate the data and analyzing the changes of economic and social indicators in 2006-2014, to observe the socio-economic impact of highway construction of Guangdong province ${ }^{15}$. 
Tab.3 Impact of economic and social of the highway during the 2006-2014

\begin{tabular}{|c|c|c|c|c|c|c|c|c|c|}
\hline Time (Year) & 2006 & 2007 & 2008 & 2009 & 2010 & 2011 & 2012 & 2013 & 2014 \\
\hline Highway mileage & 3340 & 3518 & 3823 & 4035 & 4839 & 5049 & 5524 & 5703 & 6280 \\
\hline Primary Industry & 198.8 & 209.3 & 227.5 & 240.1 & 287.9 & 300.4 & 328.7 & 339.3 & 373.7 \\
\hline Secondary Industry & 1493 & 1824 & 2409 & 3169 & 4624 & 3818 & 3981 & 5949 & 6630 \\
\hline Tertiary Industry & 454.3 & 478.4 & 520 & 548.7 & 658.1 & 686.7 & 751.3 & 775.6 & 854.1 \\
\hline $\begin{array}{l}\text { GDP increment of } \\
\text { highway mileage } \\
\text { stimulation }\end{array}$ & 2146 & 2512 & 3156 & 3958 & 5570 & 4806 & 5061 & 6764 & 7858 \\
\hline $\begin{array}{l}\text { The number of new } \\
\text { inauguration }\end{array}$ & 436 & 522 & 645 & 839 & 1096 & 1029 & 1037 & 1477 & 1651 \\
\hline $\begin{array}{l}\text { Highway maintenance } \\
\text { cost }\end{array}$ & 23382 & 24624 & 26764 & 28242 & 33874 & 35345 & 38669 & 39921 & 43960 \\
\hline $\begin{array}{l}\text { The density of road } \\
\text { network }\end{array}$ & 0.019 & 0.019 & 0.021 & 0.022 & 0.027 & 0.028 & 0.031 & 0.032 & 0.035 \\
\hline $\begin{array}{l}\text { Regional tourism } \\
\text { revenue }\end{array}$ & 3320 & 3497 & 3801 & 4010 & 4810 & 5019 & 5491 & 5669 & 6242 \\
\hline The addition of vehicle & 18.9 & 22.8 & 28.4 & 37.2 & 48.8 & 45.6 & 45.8 & 66 & 73.8 \\
\hline $\begin{array}{c}\text { Increasing Amount of } \\
\text { Highway freight } \\
\text { turnover }\end{array}$ & 71.3 & 79.6 & 94.2 & 110.7 & 147.6 & 135.9 & 145.1 & 177.6 & 202.9 \\
\hline $\begin{array}{c}\text { Increasing Amount of } \\
\text { Highway passenger } \\
\text { turnover }\end{array}$ & 8.1 & 8.5 & 9.3 & 9.8 & 11.7 & 12.2 & 13.3 & 13.8 & 15.2 \\
\hline
\end{tabular}

\section{Conclusion}

1) With the increase of highway mileage and investment, it shows significant impact on the primary industry, the secondary industry and the tertiary industry, especially for the secondary industry. It is shown by comparing the leading role from other industries to GDP that the leading role of highway construction in GDP increment over $10 \%$.

2) After run the SD model, it can be seen that the correlation of the impact from highway mileage to obtain employment is closer than the impact from highway investment to obtain employment. The more highway mileage of increased, the more Employment growth, it can account for about $20 \%$ of the whole society jobs per year.

3) The highway mileage driven the increase of vehicles ownership accounted for about $6 \%$ of the increase in the amount of vehicles ownership in the whole society. This ratio is lower than the impact of the new vehicles from other industries. In terms of the pace of development of highway construction, the rapid of vehicles ownership growth too fast. This article is recommended to control the growth of vehicles ownership by policy instruments.

4) The results of model simulation shows a significant effect of freight and passenger turnover by highway construction. The effect of the freight turnover is more strength than the passenger turnover. The highway mileage driven the increase of freight turnover accounted for about $10 \%$ of the increase in the amount of freight turnover in the whole society.

\section{Summary}

This article established the index system of social-economic of highway construction, analyzed the various indicators. Establishing the system dynamics flow diagram on the basis of the highway and national statistical bulletin data from Guangdong province. Simulating the flow chart to measure the 
leading role of the social-economic of highway construction of Guangdong provincial during 2006 to 2014. This article make a suggestion to highway construction on how to promote economic and social development more effectively.

\section{References}

[1] C.W.Yuan, Q.Q.Wu, The DEA Model of the Coordination of Highway and Regional Economic Development Journal of Changan University (Social Science Edition) [J] Vol. 11 No13 Sept. 2009

[2] Z.Y.Fan, C.Y.Xiao, Analysis of Expressway Construction Effects on National Socio-economic Development of China, Journal of Highway and Transportation Research and Development, Vol.23 No.5 May.2006.

[3] H.T.Rui, Q.Q.Wu, Y.F.Zhao, S.Z.Zhang, Influence of Highway Construction on Regional Economy Development-Taking Shanxi as an Example, Journal of Changan University(Natural Science Edition [J] Vol. 32 No.6 Nov.2012

[4] Q.He, J.Q.Liao, Model of Evaluation on Multiplier Effect of National Economic Development of Expressway Network [J] HIGHWAY Aug. 2010 No.8. [J] Journal of Highway and Transportation Research and Development Vol23 No 4 Apr 2006.

[5] K.W.Xi, F.T.Ren, Expressway Benefit Quantitative Analysis Based on Economic Potential Model Journal of Highway and Transportation Research and Development

[6] Y.Chen, Q.X.An, J.Liu, Evaluation of Socioeconomic Adaptability of Expressway in Hubei Province Based on DEAHP Model [J] HIGHWAY Jan 2010 No1.

[7] Y.Wang, S.F.Liu, S.Yang, A Practical Analysis of Contribution of Lian-Xu Expressway to Regional Economic Growth [J] HIGHWAY Dec. 2006 No. 12

[8] B.Chen, Q.Y.Wei, L.Gao, Assessment of social and economic environment of highway construction on multi-step associated gray model [J] China Journal of Highway and Transport Vol. 16 No. 1 Jan. 2003

[9] J.F.Liu, Social economic environmental influence evaluation of highway projects [J] JOURNAL OF CHONGQING JIAOTONG UNIVERSITY Vo1 23 No.2 Apr, 2004.

[10] Y.M.Zhou, J.Lian, X.N.Sun, After the evaluation system and Quantitative Evaluation Model of the Effect of Expressway [J] Journal of Highway and Transportation Research and Development Vol5.2014.

[11] X.P.Zhang, Researches on the Beijing-Shijiazhuang Freeway's Effect on the Economic and Social Development of Hebei Province [D] Jun, 2010

[12] J.P.Chen, T.Xiong, Socio-Economic Impact Analysis and Evaluation of Highway Construction Projects Engineering Economy \& Management [J] No.24 Dec, 2012

[13] Y.N.Wang, Y.X.Yun, Z.Q.Fan, Research on the evaluation and mechanism of socio-economic benefit of highway projects [J] Vol. 10 No. 142012

[14] J.Shi, Z.Z.Wu, T.Huang, Evaluation on the Impact of an Expressway Upon Regional Social Economy [J] Journal of Wuhan University of Technology(Transportation Science \& Engineering) Vol. 34 No. 5 Oct. 2010

[15] H.Y.Zhu, Y.F.Wu, An Empirical Study on the Relationship between the Construction and Operation of Highway and Growth of Economy Based on the Data of Guangdong Province [J] Academic Journal Electronic Publishing House No.2 Mar. 2010 